\title{
Fiscal Decentralization in Rural Drinking Water Supply Sector in Madhya Pradesh
}

\author{
Saifullah Khan
}

SSL Jain PG College, Haripura, Vidisha, Madhya Pradesh, India

Corresponding author: saifullahk2010@gmail.com

\begin{abstract}
The paper examines the fiscal decentralization in rural water supply sector in MP (Madhya Pradesh), covering the period from 2001-02 to 2017-18. Three types of examinations have been made in the study. The first is to find out devolvable funds in rural water supply sector, and its percentage in total rural water supply expenditure in the state. The second is to find out devolved funds in rural water supply sector and its percentage in total rural water supply expenditure, devolvable funds and plan rural water supply expenditure in the state. Finding indicates that share of devolvable funds in rural water supply expenditure is increasing continuously. All devolvable funds are revenue expenditure; it means that state government is decreasing their funds for capital expenditure and not increasing its assets in rural water supply sector. On an average during 2001-02 to 2017-18 share of devolved funds into rural water supply expenditure is just 9.5 percent. Planning Commission suggested 30-40 percent of a state's plan can be devolved to local bodies. However, on an average during 2001-02 through 2016-17, only 9.5 percent of total rural water supply budget, and only 12 percent of total planned funds of rural water supply was devolved. It has been seen in the analysis that rural water supply, despite being an important area of functional devolution; managed a financial devolution of barely one third of the lower limit of devolution prescribed by the planning commission. In the last five years during 2013-14 to 2017-18 annual growth rate of devolved funds in total rural water supply expenditure is negative (-30 percent per anum).
\end{abstract}

Keywords: Decentralisation, Devolvable Funds, Devolved Funds, Rural Water Supply, Madhya Pradesh.

The concept of fiscal decentralization has got widest recognition during the last two decade. It has been considered to most effective strategy from the point of view of welfare of the society. The 73rd Constitutional Amendment Act passed by the Indian Parliament in 1992, which enabled decentralised governance through PRIs in rural areas. PRIs offer India's rural villagers a practical opportunity to participate in village planning processes, The eleventh schedule added to the constitution by the 73rd amendment lists twenty- nine functions devolvable by states to PRIs, this constitutional amendment have also devolved the water supply responsibility to PRIs/local bodies. States were free to set the speed and design of their approach to decentralization under the general framework of the constitutional mandate. A notified functional transfer without an associated budgetary provision does not carry any operational significance ${ }^{1}$. The vital benefit of fiscal decentralization is to facilitate the local governments to give public services according to the preferences of people. Planning Commission has suggested that $30-40$ percent of a state's plan can be devolved on local bodies as untied funds ${ }^{2}$. Such devolution of funds to PRIs would create greater awareness among the people and help to empower the panchayats to plan and implement programmes of economic development and social justice at the local level in effective manner. Our study is trying to find out that in what extent Madhya Pradesh has devolved its funds in the water supply.

\section{Devolvable Funds}

Devolvable funds are those, which are purely rural in nature and should be planned and implemented 
by PRIs, in relation to 29 subjects given in eleventh schedule of the constitution. Devolvable funds are different from the total rural expenditure; because RWS budget includes capital expenditure while a devolvable fund does not include it. The reason is that all the capital expenditures directly incurred by state government departments on PRIs for construction of panchayat buildings and structures etc. In the state budget all financial assistance to PRIs are booked under the revenue expenditure, because these expenditures are of recurring nature for the state, while PRIs can use these funds for capital expenditure. That is why we are taking only revenue expenditure of total rural expenditure as the devolvable funds.

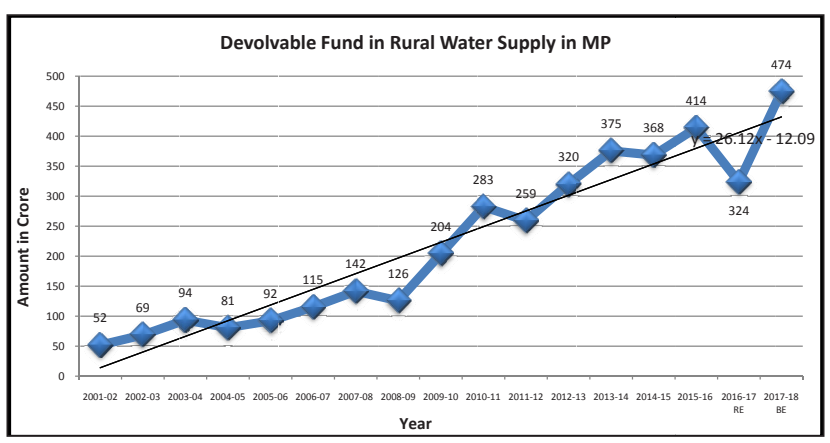

Fig. 1

Source: Computed by Author using Madhya Pradesh State Budget, Volume 3, 2001-02 to 2017-18.

In rural water supply total devolvable funds increased by 9 times during 2001-02 to 20178, increasing from ₹ 52 crore in 2001-02 to ₹ 474 crore in 2017-18. Expenditure increased by ₹ 26 crore per anum during 2001-02 to 2017-18, with the annual growth rate of 14.63 percent. The growth rate during 2001-02 to 2013-14 is 17.3 percent but during 201314 to 2017-18 growth rate is just about 3.44 percent.

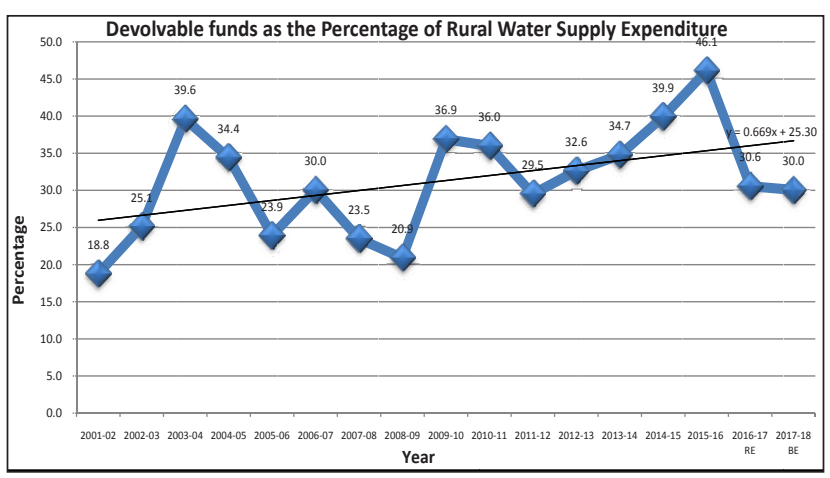

Fig. 2

Source: Computed by Author using Madhya Pradesh State Budget, Volume 3, 2001-02 to 2017-18.
On an average during 2001-02 to 2017-18 share of devolvable funds into rural water supply expenditure is about 31 percent. The largest share of the devolvable funds in rural water supply expenditure was recorded in 2015-16 when it was 46 percent, and 2001-02 was the year in which share of devolvable fund into rural water supply expenditure was recorded at its lowest 18.8 percent. The devolvable percentage is low where there is large expenditure on departmental infrastructure, means there is a high capital expenditure. Share of devolvable funds in rural water supply expenditure increased from 18.8 percent in 2001-02 to 30 percent in 2017-18.

We are taking only revenue expenditure of total rural expenditure as the devolvable funds and if share of devolvable funds is increasing as our data shows, it means that PRIs are decreasing their funds for capital expenditure. The concerning factor is that the authorities are increasing revenue expenditure (as devolvable funds are increasing) in rural water supply expenditure. Revenue expenditure is incurred to maintain the current level of services and payments for the past obligations and as such does not result in any addition to the infrastructure and service network. Capital expenditure is important for long term and all round development than the revenue expenditure. This reveals that the government of MP is not sincere, rigorous in providing safe water to the rural people, as they are increasing their revenue expenditure and not increasing assets in the sector.

\section{Devolved Fund}

Devolved funds are those funds, which has been spent through PRIs, these funds comes under the dedicated demand numbers $15,52,53,74,80,82$ (Financial Assistance to PRIs). The difference between devolvable and devolved fund is that, devolvable funds are those, which are purely rural in nature and the devolved funds are those which have been spent through PRIs.

In rural water supply total devolved funds increased by 1.65 times during 2001-02 to 2017-18, while devolvable funds increased by 9 times during the same time. Devolved funds have been increased from ₹ 16 crore in 2001-02 to ₹ 27 crore in 2017-18. Expenditure increased by $₹ 4.33$ crore per anum during 2001-02 to 2017-18, with the annual growth 
rate of 8.51 percent while for devolvable funds increment was 14.63 percent.

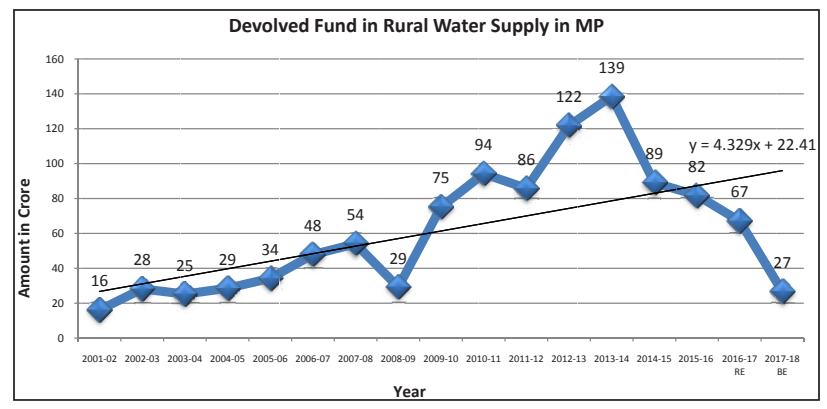

Fig. 3

Source: Computed by Author using Madhya Pradesh State Budget, Volume 3, 2001-02 to 2017-18

The growth rate during 2001-02 to 2013-14 is 17.79 percent for the devolved funds that is approximately equal to the 17.3 percent growth of devolvable funds but during 2013-14 to 2017-18 growth rate is negative by -30 percent, while for the devolvable funds it is about 3.5 percent. In the last 5 years growth rate of total state expenditure is 19 percent, social services expenditure is 22 percent, total water supply expenditure is 16 percent and rural water supply expenditure is 9 percent. It indicates that in the recent years government of MP is reducing its expenditure in rural water supply sector in comparison with all other sectors. As analysis confirms that growth rate of total state expenditure, social sector expenditure and total water supply expenditure are much higher than rural water supply expenditure. Within rural water supply expenditure growth rate of devolved funds is negative those are coming down continuously in the last five years those were stand at $₹ 139$ crore in the year 2013-14 and reached at just ₹ 27 crore in 2017-18.

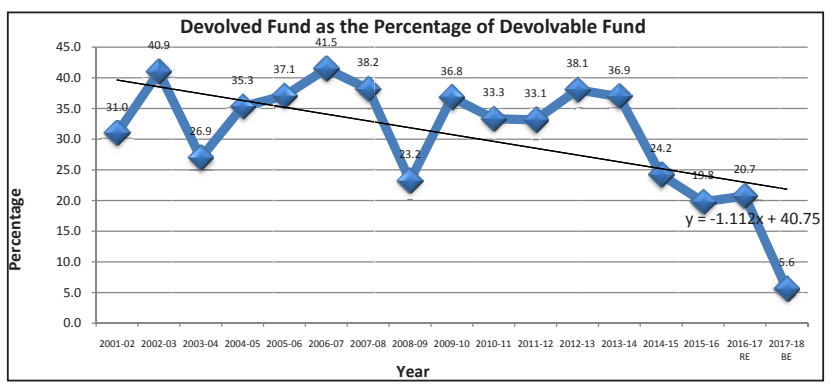

Fig. 4

Source: Computed by Author using Madhya Pradesh State Budget, Volume 3, 2001-02 to 2017-18.

On an average during 2001-02 to 2017-18 share of devolved funds into devolvable funds is about 30.7 percent. The highest share of the devolved funds in total devolvable funds was recorded in 2006-07 with 41.5 percent, and it was lowest in the year 2017-18 at 5.6 percent. During 2001-02 to 2017-18 share of devolved funds in devolvable funds registered a high negative annual growth rate of -5.34 percent. During 2001-02 to 2013-14 growth is 0.14 percent while during 2013-14 to $2017-18$ it is negative by -32.44 percent.

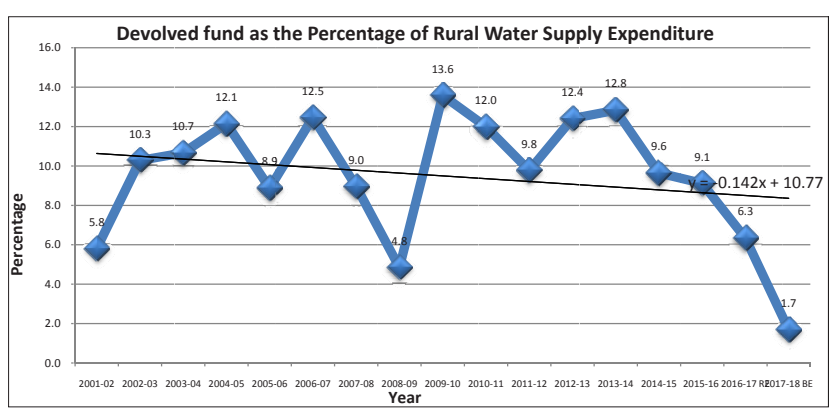

Fig. 5

Source: Computed by Author using Madhya Pradesh State Budget, Volume 3, 2001-02 to 2017-18.

The largest share of the devolved funds in rural water supply expenditure was recorded in 200910 when it was 13.6 percent, and 2017-18 was the year in which share of the devolved funds in rural water supply expenditure was recorded 1.7 percent. During 2001-02 to 2016-17 share of devolved funds in rural water supply expenditure registered a negative annual growth rate of -3.1 percent. During 2001-02 to 2013-14 growth is 2.91 percent while during 2013-14 to 2016-17 it is negative by -36 percent. On an average during 2001-02 to 2017-18 share of devolved funds into rural water supply expenditure is about 9.5 percent.

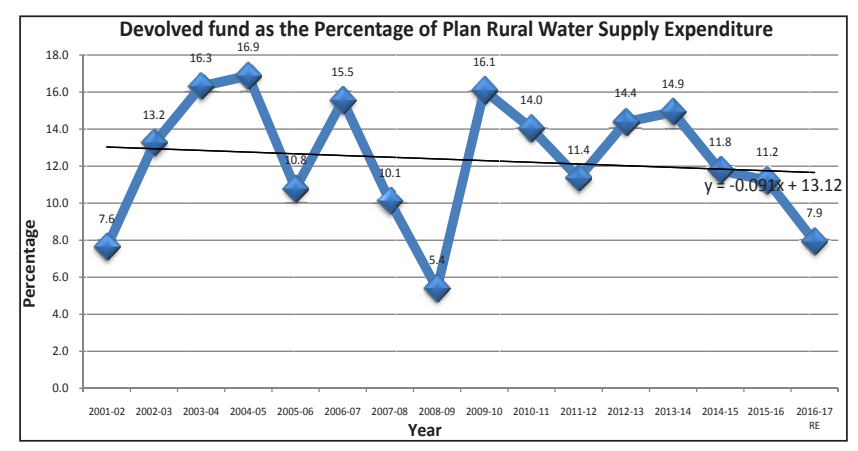

Fig. 6

Source: Computed by Author using Madhya Pradesh State Budget, Volume 3, 2001-02 to 2017-18.

The highest share of the devolved funds in plan 
rural water supply expenditure was recorded in 2004-05 with 16.9 percent, and it was lowest in the year 2008-09 at 5.4 percent. During 2001-02 to 2017-18 share of devolved funds in plan rural water supply expenditure registered a negative annual growth rate of -0.55 percent. During 2001-02 to 2013-14 growth is 1.21 percent while during 2013$14-2016-17$ it is negative by -17.67 percent. On an average during 2001-02 to 2016-17 share of devolved funds into plan rural water supply expenditure is about 12.3 percent.

Drinking water supply schemes have also suffered from poor upkeep. Responsibility for operation and maintenance of water supply schemes lies with the PRIs but in many states this responsibility is poorly defined and not supported by transfer of adequate funds and trained manpower to the PRIs. PRIs and Village Water and Sanitation Committees (VWSCs) are not willing to take over completed schemes in which they were not involved at the planning and implementation stages. The $73^{\text {rd }}$ and 74th Amendments, transferred functions to PRIs and municipalities, but there have been very little effective devolution of funds or of control over functionaries ${ }^{1}$. Planning Commission suggested 30-40 percent of a state's plan to be devolved to local bodies. Though, on an average during 200102 through 2016-17, only 10 percent of total rural water supply expenditure, and only 12.3 percent of total planned funds of rural water supply were devolved. It has been seen in the analysis that rural water supply, despite being an important area of functional devolution; managed a financial devolution of barely one third of the lower limit of devolution prescribed by the planning commission.

Decentralization is now being considered as an instrument of poverty reduction and enhancing social welfare. Decentralization focuses on the devolution of fiscal power and authority from the central and state government to local governments. It is because local governments have an important role to play in the implementation of public policies quantitative measures should be attempted to get the extent to which the functional transfer have been achieved through the budgetary transfer of funds, but state government is reducing devolved funds in rural water supply sector and the local authorities

1 Faster, Sustainable and More Inclusive Growth, an Approach to the Twelfth Five Year Plan 2012-17 are not able to spent amount at the village level according to their needs.

\section{CONCLUSION}

On an average during 2001-02 to 2017-18 share of devolvable funds into rural water supply expenditure is about 31 percent, with the annual growth rate of 14.6 percent. Share of devolvable funds in rural water supply expenditure is increasing continuously. All devolvable funds are revenue expenditure; it means that state government is decreasing their funds for capital expenditure and not increasing its assets in rural water supply sector. The concerning factor is that revenue expenditure is incurred to maintain the current level of services and payments for the past obligations and as such does not result in any addition to the infrastructure and service network. Capital expenditure is important for long term and all round development than the revenue expenditure. This reveals that the government of MP is not sincere, rigorous in providing safe water to the rural people, as they are increasing their revenue expenditure and not increasing assets in the sector.

On an average during 2001-02 to 2017-18 share of devolved funds into devolvable funds is about 30.7 , with the annual growth rate of 8.5 percent per anum, during the same time average share of devolved funds into rural water supply expenditure is just 9.5 percent. In the last five years during 201314 to 2017-18 growth rate of state expenditure is 19 percent, social services expenditure is 22 percent, total water supply expenditure is 16 percent and rural water supply expenditure is 9 percent. It indicates that in the recent years government of $\mathrm{MP}$ is reducing its expenditure in rural water supply sector in comparison with all other sectors. Within rural water supply expenditure growth rate of devolved funds is negative (-30 percent per anum). in the last five years devolved funds are coming down continuously those were stand at $₹ 139$ crore in the year 2013-14 and reached at just ₹ 27 crore in 2017-18.

Planning Commission suggested $30-40$ percent of a State's Plan to be devolved to local bodies. However, during 2001-02 through 2016-17, only 9.5 percent (average across the years) of total rural water supply budget, and only 12 percent (average across the years) of total planned funds of rural water supply 
were devolved. It has been seen in the analysis that rural water supply, despite being an important area of functional devolution; managed a financial devolution of barely one third of the lower limit of devolution prescribed by the planning commission.

\section{REFERENCES}

Govinda Rao, M., Raghunandan, T.R., Manish Gupta, Polly Datta, Pratap Ranjan Jena and Amarnath H.K. 2011. Fiscal Decentralization to Rural Local Governments in India: Selected Issues and Reform Options, National Institute of Public Finance and Policy, New Delhi, May 2011.

Madhya Pradesh State Budget, Volume 1 and Volume 3, 2001-02 to 2017-18, http://www.finance.mp.gov.in/index. htm (Accessed May 14, 2017).

Oommen, M.A. 2008, Fiscal Decentralisation to Local Governments in India, Cambridge Scholars Publishing, Copyright (C) 2008 by M. A. Oommen and contributors, ISBN (10): 1-84718-488-X, ISBN (13): 9781847184887
Planning Commission 2001. Report of the Task Force on Panchayati Raj Institutions (PRIs), Planning Commission, New Delhi, December 2001

Rajaraman, Indira and Sinha, Darshy 2007. Functional Devolution to Rural Local Bodies in Four States, Economic and Political Weekly, 42(24).

Saifullah Khan 2017. Evaluation of Physical and Financial Progress of Rural Water Supply Sector in Madhya Pradesh, Elk Asia Pacific Journal of Social Science, 4 (1).

Saifullah Khan and Dr. Shobha Jain 2017. Evaluation of SC/ ST Expenditure in Rural Drinking Water Supply Sector in Madhya Pradesh, Journal of Advances and Scholarly Researches in Allied Education, XIV(1).

Saifullah Khan and Shobha Jain 2017. Expenditure pattern in social services in MP, India Since 2001, International Research Journal of Social Sciences, 6(12): 5-15.

Saifullah Khan and Shobha Jain 2017. Public Expenditure On Rural Water Supply Sector In Madhya Pradesh - Recent Trends, International Journal of Recent Scientific Research, 8(9): 20046-20051. 
